\title{
Changes in the Attitudes of Y Generation Members towards Participation in the Activities of Municipalities in the Years 2008-2017
}

\author{
Dorota BEDNARSKA-OLEJNICZAK, Jarosław OLEJNICZAK \\ Wroclaw University of Economics, Wrocław, Poland \\ \{dorota.olejniczak, jaroslaw.olejniczak\}@ue.wroc.pl
}

\begin{abstract}
The presented research results cover a comparative analysis of cyclical surveys about attitude to social participation conducted among students (members of Y generation) of Wroclaw's economic universities in 2008, 2013 and 2017. The basic purpose of the study is to compare the attitudes to social participation of students at similar stages of life (students) and at similar age over the years 2008-2017. The second aim is to answer the question whether these attitudes have changed with the introduction of active participation of citizens through the use of the participatory budget. The survey included 40 problematic questions. In the majority of them a five-step Likert scale was applied.

The results of the survey show that the dating analysed period surveyed groups of questioned young Poles had very low interest in gmina financial activity but it was slightly rising. The feeling of real influence on local issues among the respondents is slowly rising what may result, among other things, from the fact that the processes of participatory budget in municipalities became widespread. Additionally, the percentage of people who do not feel the need to increase their impact on municipal affairs continues to raise what can be caused by existing more satisfactory possibilities for citizens to participate in the activities of municipalities.
\end{abstract}

Keywords: Social Participation, Local Government Budget, Generation Y.

\section{Introduction}

The notion of the citizens' participation in the state activities is an ambiguous one. One should refer here to one of the basic means of defining the essence of social participation proposed by Sherry R. Arnstein in 1969 [1]. According to this concept, participation refers to the influence of the "minority" (i.e., part of the local community) on management decisions. The typology of the kinds of participation was hierarchically structured along with the increasing strength of stakeholders' decisionmaking capacity. The lowest levels of the "ladder" - manipulation and therapy do not constitute the real participation since they aim at shaping the stakeholders` attitudes by managers (they are merely an "illusion of participation" - they can take the form of 
consultative groups or discussion panels moderated by managers and propagating their ideas). Further levels of participation - information, consultation and mitigation are the substitute of proper participation, since obtaining information on the tasks being carried out is not followed by the possibility of people to have an influence on their form (informing) or despite listening to stakeholders, collecting surveys, carrying out other studies, the authorities do not take any actions aiming at realization of the collected suggestions (consultations) or there is a lack of possibility to influence the representatives of stakeholders participating in the planning and implementation of the tasks on the actual activities of the authorities. The above three levels of participation represent only a "safety valve", creating an illusion that government deals with issues reported by residents. Whilst the actual participation will take the form, first of all, of partnership - where in the process of negotiation and co-responsibility stakeholders are able to influence the decisions of the authorities; secondly, it will take the form of delegated power - where stakeholders will primarily decide on the shape of the particular project; thirdly, in extreme form, participation will mean taking control of a part of the management activities in a relevant and important area.

The goals of social participation are, for example,: firstly, to inform and educate the society; secondly, to involve in the decision-making process of the managing bodies the values, suggestions and preferences of the society, thirdly, to increase the substantive character of the decisions; fourthly, to increase the confidence in the authorities; fifthly, to defuse conflicts between the negotiating parties (stakeholder groups, governing bodies and stakeholders) and sixthly, to improve the costeffectiveness of making decisions [5]. It should be noted that the sixth goal is a measure of the legitimacy of the particular forms of social participation. The breakdown of costs of the individual types of participation with achievable or expected effects often gives the opportunity to choose a more profitable form of participation.

\section{The purpose and research method}

The presented research results cover a comparative analysis of cyclical surveys about attitude to social participation conducted among students of Wroclaw's economic universities in 2008, 2013 and 2017 (unpublished yet). The findings of these examinations were published by the authors in separate papers [3,4], however, no comparative analysis has been performed. Thus, the basic purpose of the study is to conduct comparative analysis of the attitudes to social participation of members of this generation at similar stages of life (students) and at similar age over the years 2008-2017. The second aim is to answer the question whether these attitudes have changed with the introduction of active participation of citizens through the use of the participatory budget. It should be noted that, as a result of the deliberate selection, the conclusions of the comparative analysis may only be considered as an introduction to the discussion on the subject matter raised in the study. 
Surveys were carried out among students of two biggest economy schools in Wrocław (in 2008 year - 288 surveys, in 2013 year - 142 and in 2017 - 208 surveys were completed). The survey included 40 problematic questions (in 2017 it had 20 additional questions). In the majority of them a five-step Likert scale was applied. 30 questions referred to issues connected with a gmina inhabited by these students. The next 8 referred to an ideal gmina. The questions can be divided into several categories: about satisfaction about living in this gmina, knowledge of problems this gmina faces, about participation in local affairs and activities, about possibility and will to influence local finances, investments and services offered by this gmina, about information policy concerning investments, finances and budget.

\section{Forms and scale of citizens' participation}

Nowadays, in most of developed countries there are various forms of citizens' participation in the activities of the authorities. The solutions which function in Poland, however, can be considered as very limited. The basic form regulated by the law is information (through Public Information Bulletins, websites and the access to public information) and consulting processes resulting from e.g. the Act on Municipalities. Since 2012, we can observe more possibilities of participation of citizens in creating the activities of municipalities as a result of the introduction of the participative budgets by the local governments. In Poland, these procedures are usually connected with the "good will" of the authorities of individual local governments units - mainly due to the continuous lack of systemic solutions included in normative acts. However, considering the placement of this form of participation discussed above in the participation ladder, it should be noted that the features of participative budget presented in literature - especially the real impact (though usually poor in quality) of stakeholders on the direction and form of public expenditure place this form of participation at least at the level of partnership. The analysis of the projects implemented by the local government units referred to in the documents as a civic or participatory budget [2] indicates that they most often relate to the functionality or improvement of life quality of members of the local communities by realization of various investment tasks. In Poland, participatory budget is a subject of research conducted by various authors. However, this subject has not yet been analyzed profoundly. From the point of view of the analyzed issue of participatory budget researches in Poland have been carried out in the area of legal aspects and public consultations $[9,14]$ and the meaning and procedures of social participation [7, 12], however, they are mainly of pilot or review nature.

The desire to cooperate, to consociate, to work for common good, to work for others - these are important features of civil society which serve both to build positive social relationships and in addition, to raise the level of social capital, whose role in the socioeconomic development of the country is more and more often emphasized in the literature [11]. The profile of the state of civil society in Poland is one of the elements of the cyclically-published report: „Diagnoza społeczna. Warunki i jakość życia Polaków" (eng. Social Diagnosis. Conditions and quality of life of Poles). The 
2015 report [6] characterizes among other attitudes of Poles towards the common good. One of the examined issues was civil experience and competence. The places of acquisition of civic experiences and skills are voluntary organizations, activities and contacts which fill the space between the individual being and the society and between the citizen and the state [6]. The simplest measure of the state of civil society is the degree of association, the percentage of citizens who belong to voluntary organizations. In Poland in 2015, only $13.4 \%$ of respondents belonged to any organizations, associations, parties, committees, councils, religious groups, unions or circles. The analysis of the percentage of people belonging to different sociodemographic groups in 2011 and 2015 again presents the lowest share of the youngest age groups (respectively in 2011: to $24,13.5 \%, 25$ to $34,10.3 \%$ and in 2015: up to 24 years old, $10.7 \%$, from 25 to 34 years old, 11.8\%). All other age groups showed more activity in the study area. Acts on behalf of one's own community, often undertaken individually, without a formal association, remain a separate matter. Social Diagnosis indicates that this activity is just as unpopular as being affiliated to an organization. In the surveyed period, only $15.4 \%$ of the respondents were involved in activities for the benefit of the local community - the municipality, housing estates or the localities in the nearest neighbourhood. The index of social experiences and civic actions (This is an aggregate measure of social and civic experiences related to 1) voting in local elections 2) activity for the good of society 3) participation in meetings 4) work for other people or social organizations, 5) performing functions in the organization) adopted in the "Social Diagnosis" indicates a very limited range of these experiences. Poles are relatively rarely involved in activities in organizations, participation in grassroots social initiatives, public meetings or volunteering. The presented results indicate that the state of civil society and social attitudes in Poland is unsatisfactory. The youngest generation ( $\mathrm{Y}$ generation) is characterized by the lowest level of vulnerability to violation of the public goods. Due to the prospective importance of the millennium generation for shaping the future social life and the potential of having skills and attitudes different from the previous generations, it seems justified to undertake research on the changes in attitudes of young Poles towards the idea of social participation.

\section{Characteristics of $\mathbf{Y}$ generation}

The ability to participate actively in shaping the activities of the municipality refers to all its inhabitants but, as the "Social Diagnosis" states, not everyone expresses the same desire and willingness to undertake such activities. Particular attention should be paid to the dedication to social participation of the young generation, which on the one hand possesses significant potential in the form of modern knowledge, entrepreneurial attitudes, and openness to innovative solutions, and on the other hand it is commonly associated with attaining self-interest rather than social one. Such opinions derive from the characteristics describing the behavior and traits of the young generation. Literature of the subject indicates particular differences between generations present in Poland and in the world which translate into different 
professional, economic and social behaviors of these groups. Four generations are most often indicated:

- Veterans (Radio Babies, The Silent Generations) - born in 1939-1945,

- Baby Boomers - born in 1946-1969,

- Generation X (Baby Busters) - born in 1970 - 1979,

- Generation Y (Millennials) - born after 1980 [10].

The youngest generation which is the subject of analysis of this paper, is generation $\mathrm{Y}$, described also as millennials, "network generation" or generation "I". This group contains people born in 1980-2000 (those boundaries should be considered as conventional; in other literature one may encounter other date indications, such as 1980-1994, 1977-1997), brought up in the era of technological revolution, which translated into their lifestyle, work and consumption. The time when $\mathrm{Y}$ generation members grew up is extremely important because it shaped their identity and attitudes. Systemic transformation from 1989, the accession of Poland to the European Union, the opening of borders within the Schengen area - these are some of the key events shaping the generation open to new experiences, which is mobile and capable of functioning in a multicultural environment. The earlier generations created their identity in the face of the war (Baby Boomers) or in the conditions of the confrontation of the capitalist and the communist bloc, the Solidarity movement and martial law (X generation) [8]. Key features and experiences of $\mathrm{Y}$ generation include:

- growing up in the free market conditions,

- contact with new technology, whose intensive development has accompanied the development of generation Y,

- increasing standard of living and consumption,

- greater choice of education and career path,

- greater mobility and openness - easier travelling and contact with other cultures (also through the Internet and language skills),

- an excellent knowledge of the new technologies - quick acquisition of needed information, creating virtual communities, but often difficulties in direct interpersonal contacts,

- fast pace of life - change as a normal state, the ability to communicate and move quickly, do several things at once but also impatience and the desire to have everything immediately,

- change of approach to one's own life - greater individualism, self-reliance, high self-esteem and the desire for self-realization [11].

The characteristics of the $\mathrm{Y}$ generation taking into account the demographic, historical, technological and social dimensions, have been presented in Table 1. 
Table 1. Characteristic of Y generation.

\begin{tabular}{|c|c|}
\hline Characteristics & Description \\
\hline $\begin{array}{l}\text { Demographic } \\
\text { dimension }\end{array}$ & $\begin{array}{l}\text { In Poland the Y generation comprises over } 11 \text { million people, which } \\
\text { constitutes one quarter of the population. The situation is similar in } \\
\text { other key regions of the world. Massive generation which is } \\
\text { significant for shaping the future social realities. }\end{array}$ \\
\hline $\begin{array}{l}\text { Historical } \\
\text { dimension }\end{array}$ & $\begin{array}{l}\text { The generation growing up after systemic transformation having no } \\
\text { experience with the communist system and command and control } \\
\text { economy which hinders the understanding of older generations. The } \\
\text { first generation creating their consciousness in Europe without } \\
\text { territorial divisions and convinced that living in another country may } \\
\text { be easier but, on the other hand, proud of its origin and faithful to } \\
\text { local traditions. }\end{array}$ \\
\hline $\begin{array}{l}\text { Technological } \\
\text { dimension }\end{array}$ & $\begin{array}{l}\text { The generation brought up in the age of technological and } \\
\text { information revolution. An excellent knowledge of modern } \\
\text { technologies and intensive use of them in a private and professional } \\
\text { life. Virtual reality is a complement to the real world, and full } \\
\text { participation in the social world requires parallel presence in both } \\
\text { worlds. }\end{array}$ \\
\hline & $\begin{array}{l}\text { Rich Internet resources and ease of use are conducive to creating } \\
\text { millennials illusion of continuous access to knowledge and } \\
\text { competence and, as a result, of rapid self-resolution. }\end{array}$ \\
\hline Social dimension & $\begin{array}{l}\text { The priorities of the Polish Y generation are: having a wide circle of } \\
\text { friends and acquaintances, health, fame and material success. } \\
\text { Compared to older generations, millennials have more friends (on } \\
\text { average more than 40) and a larger network of acquaintances (on } \\
\text { average more than 200) with which they maintain constant contacts. } \\
\text { Polish millennials are more sensitive to economic stimuli than their } \\
\text { western counterparts living in the conditions of the economic } \\
\text { prosperity and stable economic situation. Y generation is convinced } \\
\text { that life success is a consequence of diligence and the acquisition of } \\
\text { the necessary competences which means continuous improvement } \\
\text { and participation in various types of courses. }\end{array}$ \\
\hline
\end{tabular}

It should be noted that in the case of Y generation there is a large age span between its members. Therefore, it appears to be a good basis for undertaking research into the evolution of attitudes of members of this generation at similar stages of life (studies) and at similar ages over the years. Taking into consideration the characteristics of $Y$ generation, its age range and the role it will play in shaping the future socio-political realities, the issue of how millennials are willing to contribute to shaping the activities of the communities in which they live seems to be important. The next part of the article will discuss this topic. 


\section{$5 \quad$ Results and discussion}

The primary concern for reflecting the level of awareness of being a member of a local community and feeling connected with it is the participation of the respondents in local elections. The comparison of the 2008, 2013 and 2017 survey results shows a gradual decrease in the proportion of people participating in these elections in the following years (question 5, fig. 1). This signals a potential decrease in citizens' interest in participation in municipal activities. At the same time, this constitutes a reflection of general tendency in the Polish society. It means a decreasing interest in public affairs, which may result from many factors, both related to the characteristics of $\mathrm{Y}$ generation and stemming from external factors.

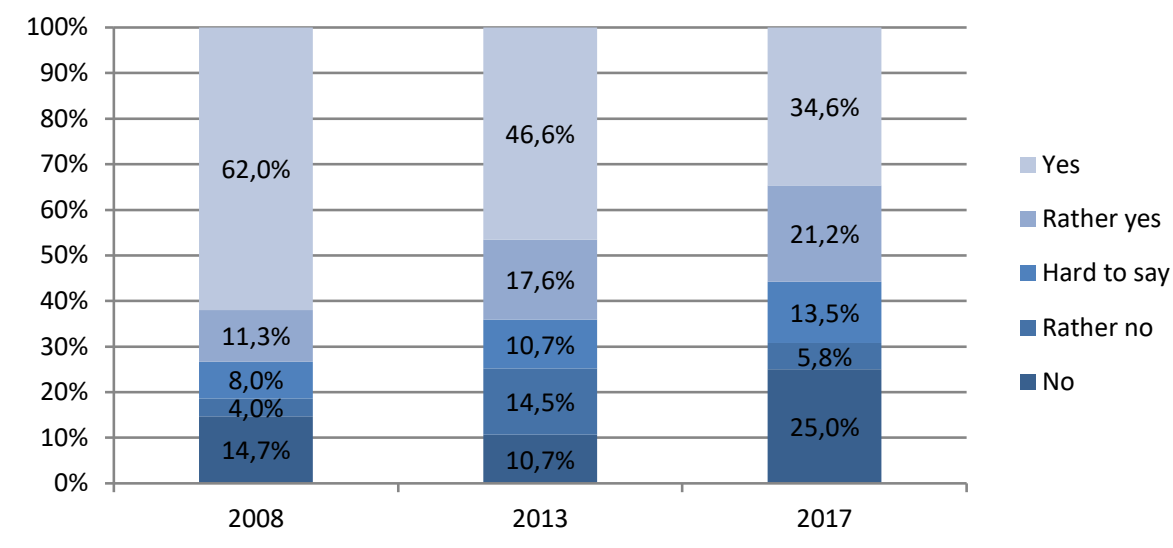

Fig. 1. Q5 I'm participating in local government elections.

While comparing the subsequent groups of respondents, it should be noted that low feeling of real influence on local issues among the respondents was observable (from 13 to $18 \%$ of them stated that they have an impact - fig. 2) - but in 2017 it was higher than in previous years. This may result, among other things, from the fact that the processes of participatory budget in municipalities became widespread. On the other hand, researches show (fig. 3) that the percentage of people who do not feel the need to increase their impact on municipal affairs continues to raise (from $10.7 \%$ in 2008 to $29 \%$ in 2017). This may partially stem from the fact that current possibilities for citizens to participate in the activities of municipalities are becoming satisfactory, and partially that the respondents' interest in local affairs diminishes. 


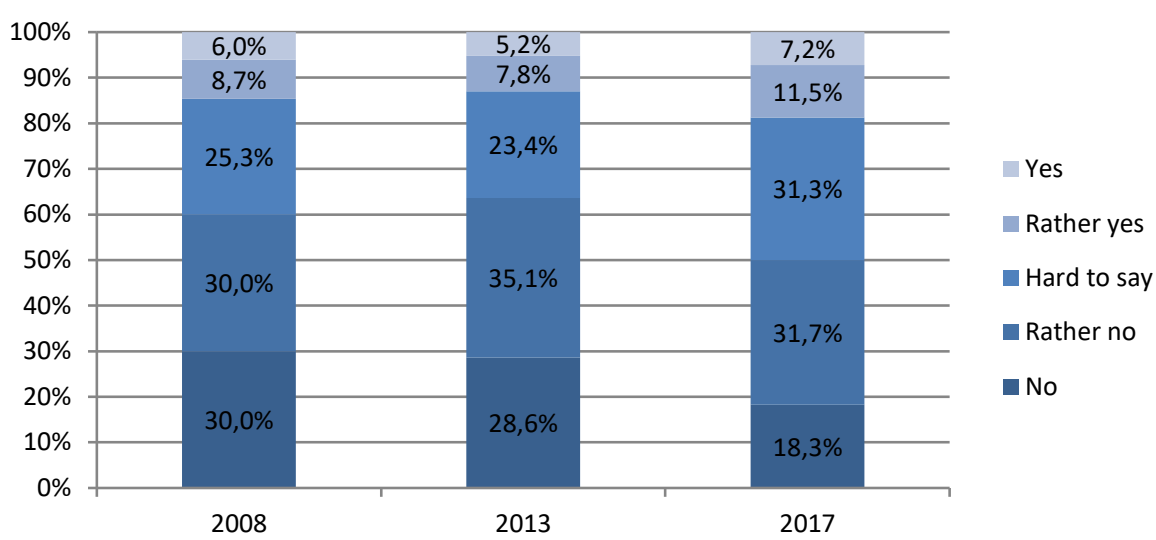

Fig. 2. Q19 I can have a real influence on municipal affairs.

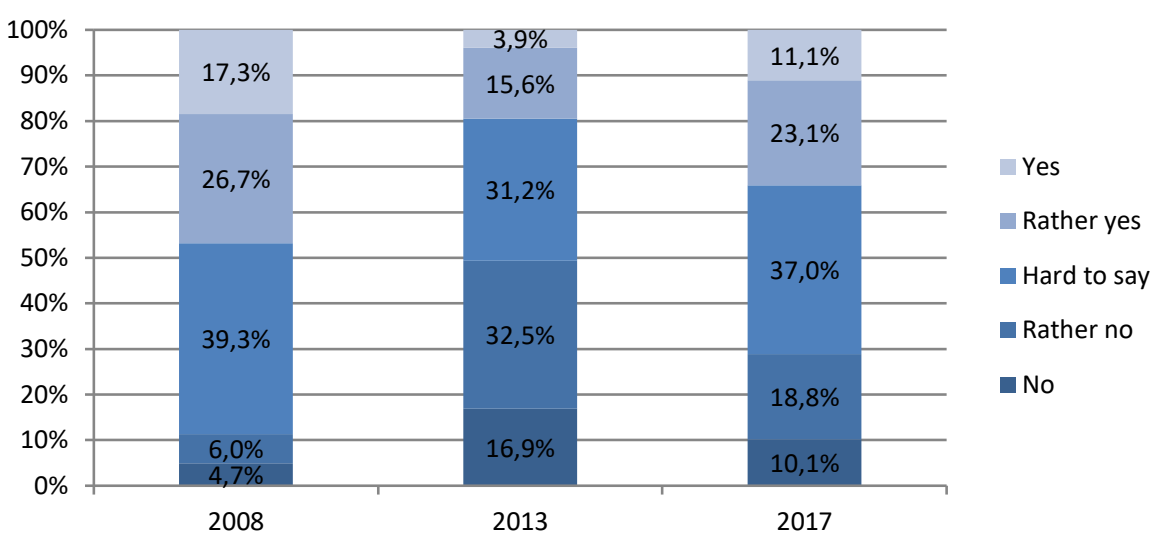

Fig. 3. Q22 I would like to have bigger influence on municipal affairs.

The survey results clearly show a negative trend - the interest in expenditure directions and investment activities of municipalities is decreasing. Between 2008 and 2017 it was a decline of 9 to 10 pp (questions 9 and 10 - fig. 4 and 5). As it can be observed, less than one third of the respondents were interested in how municipalities distribute public money. On the other hand, the confidence in the effectiveness of consultative processes introduced by local governments grew slowly from about $11 \%$ in 2008 to more than $16 \%$ in 2017 (fig. 6). Nevertheless, still more than half of the respondents pointed out the lack of effective communication procedures with officials in this regard. 


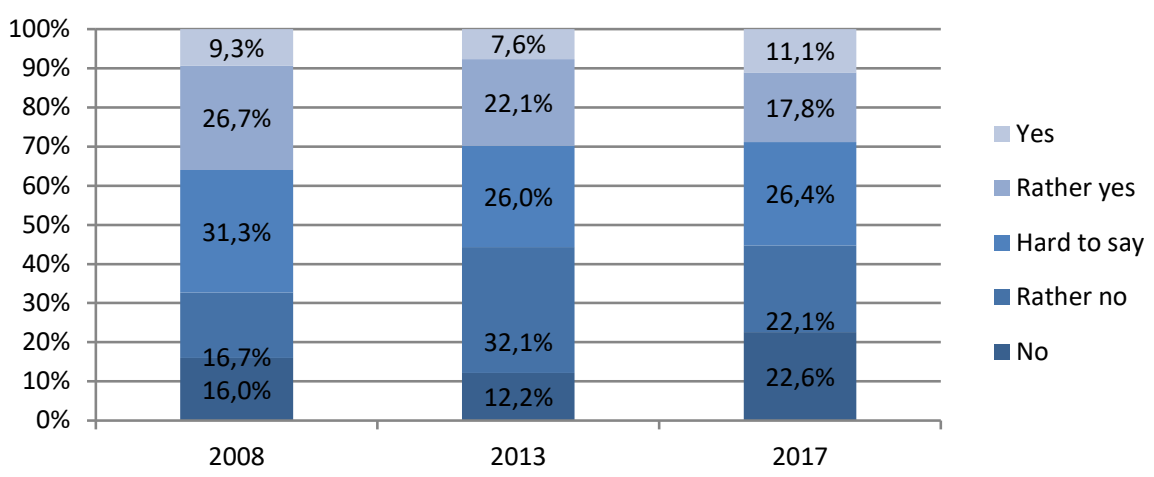

Fig. 4. Q9 I follow expenditure dimensions of local authorities.

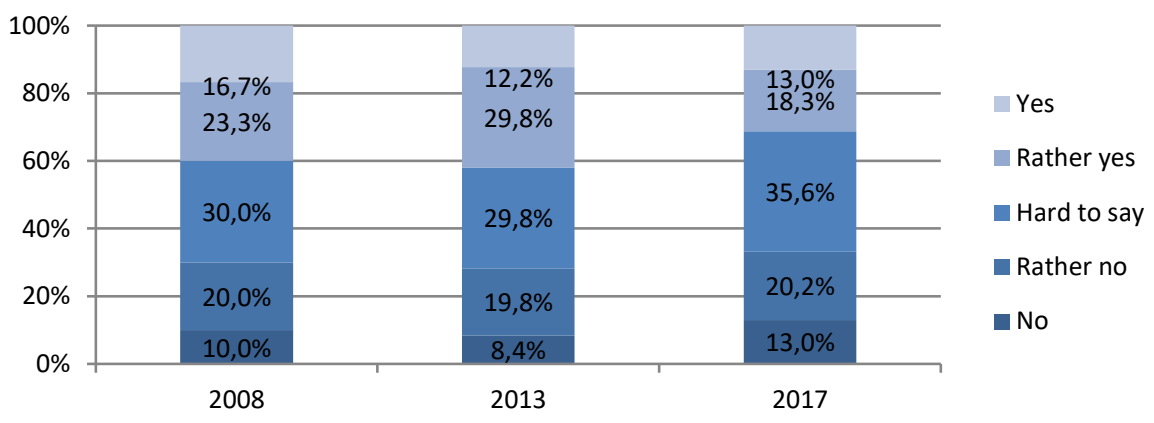

Fig. 5. Q10 I follow investments plans and activities of local authorities.

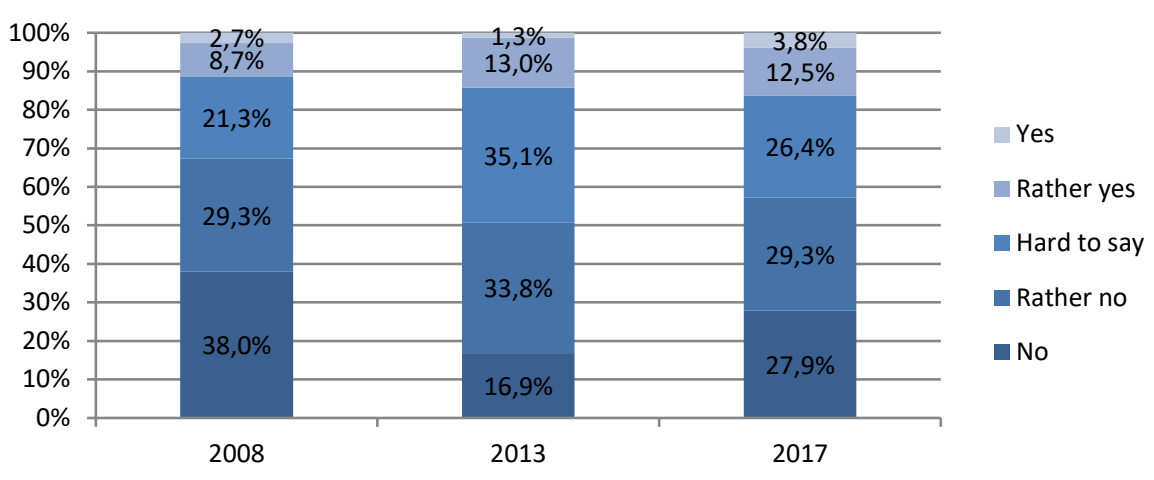

Fig. 6. Q24 There are effective communication procedures with officials concerning investment plans.

The last issue which is worth mentioning is the level of social activity of the respondents. As it can be seen, the majority of the respondents basically do not 
participate in processes of public consultation conducted by municipalities. Naturally, there was more than twofold increase in the percentage of respondents declaring participation in consultations (from 6.7 to $13.9 \%$ of respondents), but this is still a very poor result. The level of participation is in this case similar to the level of participation of respondents in the activities of municipal social organizations approximately double increase as well (from 5.4 to $11.1 \%$ ).

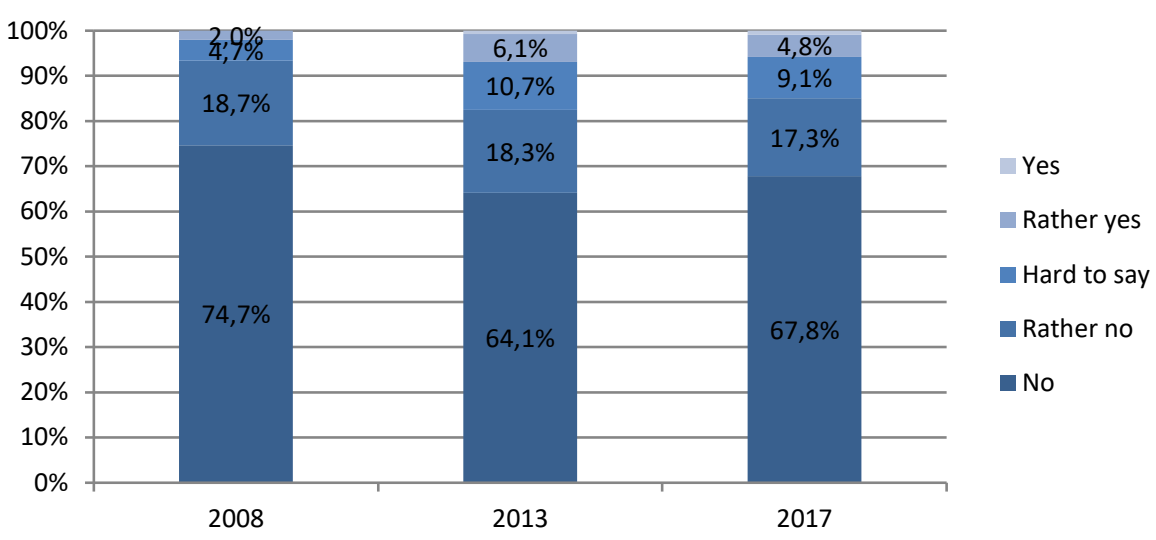

Fig. 7. Q3 I participate in processes of public consultation conducted by municipalities.

\section{Conclusion}

The results of the survey show that the dating analysed period surveyed groups of questioned young Poles had very little interest in gmina financial activity but it was slightly rising despite a gradual decrease in the proportion of people participating in municipal elections in the 2008, 2013 and 2017. The feeling of real influence on local issues among the respondents is slowly rising what may result, among other things, from the fact that the processes of participatory budget in municipalities became widespread. Additionally, the percentage of people who do not feel the need to increase their impact on municipal affairs continues to raise what can be caused by existing more satisfactory possibilities for citizens to participate in the activities of municipalities. The other thing is general attitude of $\mathrm{Y}$ generation to citizen (social) participation - millennials are not willing to contribute to shaping the activities of the communities and they generally are not interested how municipalities distribute public money. 


\section{References}

1. Arnstein, S. R.: A Ladder of Citizen Participation. Journal of the American Planning Association 35(4), 216-224 (1969).

2. Bednarska-Olejniczak, D., Olejniczak, J.: Participatory Budgeting in Poland - Finance And Marketing Selected Issues. In: Jedlicka, P., Marešová, P., Soukal, I. (eds.), Hradec Economic Days 2017, vol. 7(1), pp. 55-67. University of Hradec Kralove, Hradec Kralove, (2017).

3. Bednarska-Olejniczak, D., Olejniczak, J.: Civil Society - the Issue of Youth Participation in the Activity of Territorial Governments Based on the Example of Students of Economy Schools from Wroclaw. In: Agrarian Perspectives XVII. Challenges For The 21st Century, vol. 1, pp. 435-438. Ceska Zemedelska Univerzita, Prague (2008).

4. Bednarska-Olejniczak, D., Olejniczak, J.: Obywatele jako świadomi uczestnicy procesów decyzyjnych w gminach. Zeszyty Naukowe Wyższej Szkoły Bankowej we Wrocławiu 5(43), 15-25 (2014).

5. Beierle, T. C.: Using social goals to evaluate public participation in environmental decisions. Review of Policy Research 16, 75-103 (1999).

6. Czapiński, J., Panek, T.: Diagnoza społeczna 2015. Warunki i jakość życia Polaków. Rada Monitoringu Społecznego, Warszawa (2015).

7. Czarnecki, K.: Udział mieszkańców w ustalaniu wydatków budżetu gminy w ramach tzw. budżetu partycypacyjnego (na przykładzie Torunia w latach 2013-2014). Prawo Budżetowe Państwa i Samorządu 2(1), 125-145 (2014), DOI: 10.12775/PBPS.2014.008.

8. Kisiel, P.: Millennialsi - nowy uczestnik życia społecznego? Studia Socialia Cracoviensia 1(14), 83-94 (2016), DOI: 10.15633/ssc.1876.

9. Krajewska, A., Sawicki, A.: Referenda lokalne - regulacje prawne, dotychczasowa praktyka i pożądane kierunki zmian przepisów, https://pbn.nauka.gov.pl/sednowebapp/works/699178, last accessed 2017/04/30.

10. Lain-Kennedy, J.: Job Interviews for Dummies. John Wiley \& Sons, Inc., New York (2007).

11. Nagaj, R.: Działania zbiorowe i na rzecz innych - analiza porównawcza polskich, litewskich i hiszpańskich studentów. Prace naukowe Uniwersytetu Ekonomicznego we Wrocławiu, 449, 450-461 (2016), DOI: 10.15611/pn.2016.449.40.

12. Olejniczak, J., Bednarska-Olejniczak, D.: Participation of Non-Resident Students in the Creation of Participatory Budget in Wroclaw. Procedia Economics and Finance 25, 579589 (2015), DOI: 10.1016/S2212-5671(15)00772-8.

13. Stachowska, S.: Oczekiwania przedstawicieli pokolenia $\mathrm{Y}$ wobec pracy i pracodawcy. Zarządzanie Zasobami Ludzkimi 2, 33-56 (2012).

14. Wierzbica, A.: Referendum i wybory oraz zarządzenia i uchwały jednostek samorządu terytorialnego: władcze, administracyjnoprawne formy wyrażania woli przez jednostki samorządu terytorialnego. LexisNexis, Warszawa (2014). 